\title{
Influence Of Contract Management Practices On Service Delivery In The Public Sector: A Case Study Of Uganda Civil Aviation Authority
}

\author{
Mr. James Anthony Kenyi*, Dr. Peter Wamalwa Barasa, PhD ${ }^{* *}$ \\ * School of Business and Economics, Mount Kenya University-Thika, O/C UNMISS HQ, BOX 29 -8111 JUBA, SOUTH SUDAN \\ ${ }^{* *}$ School of Business and Economics, Mount Kenya University-Thika, P.O BOX 42702- 80100, MOMBASA KENYA \\ DOI: 10.29322/IJSRP.11.10.2021.p11820 \\ http://dx.doi.org/10.29322/IJSRP.11.10.2021.p11820
}

\begin{abstract}
The common trends in the business world, organizations are majorly concerned with contractors discharging their duties through appropriate contract management procedures in a safe and timely manner (Hotteebex, 2013). Contract management involves all activities of administration concerned with managing contracts which include; appointing the contract manager or constituting the contract management team, planning contract implementation, management of quality, administering the contract, and monitoring contract implementation. The study sought to examine the influence of contract management practices on service delivery in the public sector with focus on Uganda Civil Aviation Authority. It focused on examining the influence of contract mobilization practice on service delivery in the public sector with focus on Uganda Civil Aviation Authority; examined the influence of contract monitoring practice on service delivery in the public sector with focus on Uganda Civil Aviation Authority and finally to evaluate the influence of relationship management practice on service delivery in the public sector with focus on Uganda Civil Aviation Authority. The study was anchored on the agency theory, Best Value Theory, Transaction Cost Theory and Contract Management Theory. It covered a sample of 152 respondents out of target population of 263 using a cross sectional case study design. It registered responses from 110 respondents. Both qualitative and quantitative methods were used integrating both descriptive and inferential statistics. Data was collected using selfadministered questionnaires, interview guides and review of documents. The analysis of findings involved use of frequencies, hypothesis testing, analysis of variance, and Pearson's linear correlation coefficients in bivariate and multivariate regression of Contract Management and Service Delivery in Uganda Civil Aviation Authority. It was established that Contract Management practices have a moderately strong positive influence on service delivery in Uganda Civil Aviation Authority given $r=0.683$ with levels of significance at $p=0.000$. Relationship management practice was found to have a stronger positive influence on service delivery compared to Contract Mobilization practice and Contract monitoring practice. The study recommends greater focus on relationship management practice as key practice of Contract management as the best guide in the attainment of better levels of service delivery in the public sector.
\end{abstract}

\section{INTRODUCTION}

T $\mathrm{t}$ is a common trend in the business world today that organizations engage contractors or suppliers by organization in the production activities in order to meet their intended outcomes (Kumar and Markeset, 2007). Many organizations are majorly concerned with contractors discharging their duties through appropriate contract management procedures in a safe and timely manner (Hotteebex, 2013). The PPDA Act of 2003 sets out contract management to be all those activities of administration concerned with managing contracts which include; appointing the contract manager or constituting the contract management team, planning contract implementation, management of quality, administering the contract, and monitoring its implementation.

In addition, contract management also encompasses contract completion which covers the preparation of a final deliverables report, the final acceptance or handover, managing defects liability or warranty periods, archiving records, processing payment, project commissioning and close out. Broadly as laid down the PPDA Chart 5 as revised by 2014, contract management entails three major phases: appointment of the contract management authority, monitoring contract implementation, and contract completion. Following the 2014 PPDA amendments on the Contract Management process, Regulations 47 and 48 provide for the release of guarantee and reconciliation of payments against deliverables. Lonegan and Bernadette (2007) note that increased social accountability and service delivery pressures by citizens on public establishments, contract management has gained significance as a key organizational activity.

However, Lock (2003), observes that challenges of contract management have become chronic across all sectors and organizations whether public or private. This is attributed to the lack of transparency and ill record keeping practices. Weele, (2002) notes that, for contract management to be a success there should be procurement of items of the right quality, quantity, cost, from the right source, with delivery made at the right place and time. In similar contention with the World Bank's position, Kramer (2003) notes that attaining the goals of improved quality, timely delivery, and reduced cost in the procurement of goods and services, is largely dependent on effective contract management. Nguyen, (2013) notes that Uganda Civil Aviation Authority as public entity has notably faced high level of risk in managing its 
contracts. As required under by law all contracts in the public sector that exceed certain thresholds should be subjected to formal and open tendering processes (Office of Government Commerce, 2012). When contracts are awarded by the contracting authority, proper management of such contracts plays a pivotal role to the delivery of expected levels of service. Similarly, the South African National Treasury Report (2010) notes that public sector entities are looking at maximum returns on investment in order to deliver more services of high level to the public.

In a global perspective, the World Bank (2017) notes that hedging against unintentional expiry of contracts and the possibility of failure to realize value for money from contracts, there should be an integrated and flexible contract management programme. In the dimensions more specific to service delivery, the World Bank adds that, securing the commitment of parties in a contract of procurement and supply to time, cost, quality and other agreed matters, requires effective contract management. To attain value for money and optimal contract outcomes, contract management should involve systematic and efficient planning, execution, monitoring and evaluation.

By the turn of $19^{\text {th }}$ century most European countries began and engaged in liberalized economies of production by engaging the private sector in the delivery of services through formal contract awarded and monitored by the government departments not only in central governments, but also in local governments service sectors (Darwin, Duberley and Johnson, 2000; OECD, 2008). In other developed economies such as USA, the onset of contracting by way of outsourcing in the 1920s set the genesis of monitoring government service provision (Weele, 2002). Equally, Asian developed economies like Japan and China had by the turn of $19^{\text {th }}$ century begun involving private contractors in the delivery of public services (Hunja, 2003). Effective contract management in all countries therefore became a focus because it was a means of ensuring and serving national interest and needs in form of service delivery.

In Africa, the underdevelopment of local capacity during the colonial era under the decentralization policy of governance ushered in the use of contractors in the service delivery programmes of colonial powers especially for civil works, supply of goods and services (Hunja, 2003; World Bank Report, 2005). In East Africa, Komakech (2020) recognizes that the key to realization of value for money and sought project outcomes by government establishments is effective contract management. Throughout the entire contract management cycle, efficient contract administration, performance monitoring and planning are critical elements. In addition, Oluka and Basheka (2012) emphasize that; if effective and efficient delivery of service is to be achieved, contract management is undisputedly important to delivering this cause in public procurement.

In East Africa, the study by Kibogo (2014) on factors influencing contract management in the public sector in Kenya. The findings revealed that contract management in public procurement is greatly influenced by styles of management, competence of employees, and information technology. Gathai et al., (2012) conducted research on how performance contracting was being implemented in Kenya Civil Aviation Authority between 2008 and 2012. Adopting descriptive statistics, the study found out that targets are mutually agreed upon and such targets are in line with objectives of the organisation. Whereas focus was on the human resource realm, it was conducted in the public sector agency and in the aviation sector as well. The study was conclusive on the importance of contract performance measurements in evaluating, controlling, and improving operations. In Tanzania, a study by Mwakyelu (2019) on contract management revealed that strategic decisions and right contract drafts greatly impact on how such contracts are managed.

Currently in Uganda, contract management in the public sector is largely enshrined in and dependent on the PPDA regulatory framework consisting of the 2003 principal Act and the attendant regulations; Local Government PPDA Regulations and Guidelines of 2006 together with the amendments thereto of 2011 and 2014. Also, under this legal framework is the structuring including: the PPDA authority as an institution to oversee and regulate the effective management of contracts in public entities; the procuring and disposing entities (PDEs), accounting officers, contract/tender committees, procurement and disposal units (PDUs), causation of establishment of evaluation committees, and user departments (UDs). As provided under the PPDA Act 2003, different roles and functions are discharged by these structures and institutions in the procurement and contract management processes of any public entity in Uganda.

According to the OECD (2008), service delivery is defined as an immediate output of the inputs into a particular operation or system. Such inputs include: workforce, procurement of supplies and finances. It therefore denotes a recipients' rational measure of output realized from particular resource inputs. An increase in inputs should lead to a relative improvement in service delivery. On a further note, the OECD advances that the core function of any established system is to ensure that quality services are available and accessible. Whereas the OECD advances access, availability, utilization, and coverage as service delivery measures; the World Bank (2013) advances service delivery indicators of: adequacy, excellence, economy, time management, ease of access, propinquity and particularly value for money that are critical metrics of service delivery within the public sector setting.

O'Neill and Lymon (2008) conceive service delivery as the deliberate obligation of public that is appointed or elected to deliver supplies or services to citizens. From the lenses of attitude or disposition, they assert service delivery as service values and norms that meet international standards. From the public sector perspective, service delivery denotes a link constituted by services, their supporting systems, policy making, service provision, and the consumption of those services. The Decentralization Policy Strategic Framework of 2004 sets out service delivery as a mechanism of public entities for meeting the aspirations and needs of intended beneficiaries, and it is against such that technical and political assessments are made (Uganda, Ministry of Local Government, Decentralization Policy Strategic Framework, 2004)

Public confidence in government entities is attained only when they are to deliver service in manner that meets the needs of the citizenry while keeping quality in balance. It is a score of credibility and legitimacy if government entities are able to deliver service that meets national needs. However, it is critical tested for government entities when they fail to deliver service to the expectations of the people. Hence, the service delivery package of any public entity should center on being accountable, ensuring 
value for money prevails, improving communication and inclusive decision-making processes. Weakness of the accountability system in place compromises the attainment of value for money.

Uganda Civil Aviation Authority which was at the time of its creation in 1994 was called Civil Aviation Authority, is a government agency administered by the Ministry Works and Transport charged with the responsibility to license, monitor, and regulate civil aviation matters in Uganda (Tajuba, 2015). In addition, Uganda Civil Aviation Authority is mandated with coordinating, regulating and overseeing Uganda's aviation industry that includes; air search and rescue, controlling air traffic, airport and aerodrome ownership, the Ugandan and international aviation law as well as representing Uganda in all aviation matters and within the international aviation community. As of October, 2016, the administrative and operational structure of Uganda Civil Aviation Authority constituted six directorates including: Corporate Affairs; Airports and Aviation Security; Safety, Security and Economic Regulation; Finance; Air Navigation Services; and Humana Resources and Administration (CAA, 2016). In July 2019, the CAA Amendment Act 2019 that changed the name of the agency Civil Aviation Authority, Uganda to Uganda Civil Aviation Authority was signed by the President of Uganda (Nakaweesi, 2019). However, despite Uganda Civil Aviation Authority missions, a lot of concerns have been raised about Uganda Civil Aviation Authority service delivery because of poor contract management practices. The poor service delivery by Uganda Civil Aviation Authority was thought to be due to how it managed its contracts. This is because contract management at Uganda Civil Aviation Authority has been associated with problems.

\section{Specific Objectives of the Study}

i. To examine the influence of contract mobilization practice on service delivery in Uganda Civil Aviation Authority.

ii. To examine the influence of contract monitoring practice on service delivery in Uganda Civil Aviation Authority.

iii. To evaluate the influence of relationship management practice on service delivery in Uganda Civil Aviation Authority

\section{LITERATURE REVIEW}

The study adopted the following theories; Agency theory, Best Value Theory, Transaction Cost Theory and Contract Management Theory

\section{Conceptual Frame work}

A conceptual framework denotes a model of how logic is made of the relationships that exist among factors that constitute or form the problem (Sekaran, 2003).

\section{Figure 1: The Conceptual framework}

\section{Independent Variables}

\section{Contract Mobilization Practice}

- Clarification of responsibilities

- Appointment of managers and teams

- Proposing changes or substitutions

- Contract documentation

Contract Monitoring Practice

- Compliance checks

- Progress reporting

- Interim payments

- Site meetings and briefs

\section{Relationship Management Practice}

- Notification of relevant personnel

- Effective communication

- Role clarity

- Harmonization of requirements

- Conflict resolution

- Government regulations and policies

- PPDA regulations and guidelines

- Personnel Skills and competences

Intervening Variables 


\section{Influence of Contract Mobilization Practice on service delivery in Uganda Civil Aviation Authority.}

According to Taylor (2009) contract mobilization involves the steps commencing with the award of contract to the most economically advantageous bidders to executing contracts and transition. Errigade, and Mclloy, (2002) advance contract mobilization to denote all preparatory activities of the procuring entity/employer and the contractor after signing of the contract but before the commencement of contract execution activities. It is a level of the contract management process involving preparation by the contractor mainly towards ensuring successful execution of the contract. On the other hand, Reader (2019), views contract mobilisation to begin with the commencement of pre-award activities right from commencement of procurement. He notes that for mobilisation to be a success, the procuring or client organisation should clearly scope out the outcomes and programming them sufficiently throughout the procurement process.

Reader (2019) however notes that, to the contractor, mobilisation involves the cooperation between the client and contractor that brings on board other line management and specialist personnel of the client who may not have been involved in the preceding procurement process activities up to award of contract. To achieve long-term success of contract, effectively mobilising, implementing and managing the transitioning process is important. Errigade and Mclloy, (2002) note that, if mobilization of contract is a success, it sets the cornerstone and foundation of contract success. Key resources like funds, contract management human resources, timeframes or schedules of work, delivery standards, variations management, inter alia are set out by the parties which define their expectations of the other during contract management.

Reader (2019) advances that, dedication and early involvement of specialists in contract mobilisation activities drawing representation from both the client and the contractor, aids the smooth running of the project, consistence and creates a sense of partnering amongst parties. From the views of Reader and other authorities, it is noted that communication, planning, agreeing to flexible timescales, securing advance approvals, establishing stakeholder expectations and key performance indicators, as well as multidisciplinary and collaborative approaches are critical components of effective contract mobilisation. How these have been integrated in the contract management efforts of Uganda Civil Aviation Authority was the focal establishment sought by this study.

\section{Influence of Contract Monitoring Practice on service delivery in Uganda Civil Aviation Authority.}

Anglin and Good (2009) state that contract monitoring involves the collection and analysis of information that is the basis of assuring the entity that progress is being made within set timeframes and that expected contract deliverables are being met. It involves measuring, reporting and monitoring of key performance indicators set out in the contract. Anglin and Good further suggest that, the areas to monitor include checking compliance with specifications of supplies and services, timeframes and quality standards. It also measures customer satisfaction, actual against planned performance, payment processes and managing the entity's compliance with terms and conditions of contract.

According to CIPS, (2014) focus of contract monitoring should be on: revealing performance deficiencies, potential of misunderstood requirements, evaluating communication effectiveness; identifying poor management of data; contract variations and the incapacitation of the contractor. The PPDA regulation 263 (2) provides monitoring and reporting systems, communication and record keeping protocols. These include; drawing up a checklist covering key timeline deliverables and performance reporting through progress report submission, supplies and service delivered certification of work done, interim payments, and contract site meetings, update and maintain complete contract records. It also provides for the scheduling of meetings for the life of contract to brief members or stakeholders at specific times.

Because contracts for the procurement of works are of higher value than those of supplies and services, they take up a significant portion of the national budget yet they are reported to be performing poorly. In a public establishment like Uganda Civil Aviation Authority, works contracting plays a significant part in determining the quality of service delivered. Thus, how contract management is achieving service delivery targets through monitoring mechanisms and within budgets so as to realize economy in Uganda Civil Aviation Authority was the focus of this study.

\section{Influence of Relationship Management Practice on service delivery in Uganda Civil Aviation Authority.}

The Office of Government Commerce (2002) recognizes that the critical success factors of contract management primarily include effective management of relationships and administration of contracts. Relationship management practice is the set of activities constituting the process that involves managing the commitment of the procuring entity and contractor, understand, agree, and whenever possible codify the interactions between them (Chartered Institute of Procurement and Supply, 2013). The Office of Government Commerce (2002) further notes that, effective contract governance will ensure that if the end user receives what was agreed upon and to the standards of quality expected, then contract management is said to be effective. Continuous monitoring of the contract is essential to ensuring that value for money is delivered to the end user on a continuous basis. This view signals the integration and importance of relationship management as a key element of good practice contract management in Uganda Civil Aviation Authority that should be consistently pursued with other elements to realize intended outcomes in service delivery.

According to the World Bank (2017), relationship management is a modern strategic approach to achieving overall performance improvement of their strategic contractors, delivery of which requires a high degree of procurement maturity, commitment and resources. The Chartered Institute of Procurement and Supply (2013) views relationship management as the process that involves managing the commitment of the procuring entity and contractor, understand, agree, and whenever possible codify the interactions between them. Mampane (2012) closely views relationship management as supplier relationship 
management encompassing a whole range of activities involving the selection and engagement of service providers, executing supply orders to performance measurement, reporting, and improvement.

According to CIPS (2013), Notification on personnel relevant to the contract, clarifying roles and responsibilities, and structuring communication within ongoing contracts are critical to realisation of service delivery targets. World Bank (2018) further notes that, "the luck of an effective interface management system could have a negative impact on the cost and contract schedules. This entails identification of contact persons with sufficient authority, clearly defining roles and responsibilities, sharing regular reports on performance and critical issues. Also, arrangements for effective conflict resolution, sharing of risks and a common risk management plan established. Similarly, for the client to strike the balance between this array of interface management elements and other relationship management aspect to attain the best value for money, the opportunity lies in effectively managing service delivery - an element that was sought to be established by the current study in Uganda Civil Aviation Authority.

\section{RESEARCH MethodOLOGY}

\subsection{Research Design}

According to O'Sullivan et al. (2007) in Abutabenjeh and Jaradat (2018), a research design is plan guiding decisions on what data, from who, when, how to collect and analyse it. This study adopted a phenomenological and positivist approach, executed in a cross-sectional duration, following a case study research strategy. It used both qualitative and quantitative methods that integrated both descriptive and inferential statistics to analyze, interpret and draw conclusions from the data collected. According to Kumar (2011), social science most commonly uses crosssectional studies as the research duration. It was adopted by the study to aid examination of the influence of contract management practices on service delivery phenomena by a cross-sectional analysis of the population of Uganda Civil Aviation Authority.

A phenomenological and positivist approach was adopted for this study because reliance was placed on the respondents' experience of phenomena under study that is, contract management practices and service delivery while envisaging a positive relationship between them to justify the use of quantitative analyses. The justification for the choice of a case study research strategy is that, it uses subjects with attributes common to other population elements instead of conducting a whole population study. In investigating this, the researcher was able to dwell on the information from Uganda Civil Aviation Authority for deductions and generalization on the management of contracts and delivery of service within the public context in Uganda.

The study adopted a mixed methods design involving both qualitative and quantitative methods. Cresswell (2014) asserts that, mixed methods design involves integrating both quantitative and qualitative methods and data. This form of inquiry assumes a combination of qualitative and quantitative methods to provide a more complete insight into phenomenon being studied that relying on a single approach. Thus, the study analyzes, interprets and draws conclusions basing on descriptive and inferential means. This involved using frequencies, mean and standard deviations, hypothesis testing, analysis of variance (ANOVA), Pearson's linear correlation coefficients in bivariate and multivariate regression analysis of findings on contract management practices and service delivery in Uganda Civil Aviation Authority.

\subsection{Target Population}

Kumar (2011) defines study population as those individuals who provide information required to answer questions and or test hypotheses of the study. Uganda Civil Aviation Authority has a population of 897 staff. Therefore, for feasibility of research activity, this study adopts a sampling frame from this big population. Kabir (2016) defines a sampling frame to constitute those population elements or the entire population with the contact information appropriate for the study. Hence, the study adopted a sampling frame of 263 including the 6 Directors from the 6 Directorates of Uganda Civil Aviation Authority, 13 staff of the Procurement Unit, 5 Contracts Committee staff, 62 Marketing and Commercial services staff, 53 Internal Audit and Risk Management, 24 Quality Assurance staff, 22 Managers, 23 Finance and Accounting staff, and 55 Engineering, Planning and Development as shown in Table1

\section{Table 1: Sampling frame}

\begin{tabular}{ll}
\hline Category of respondents & Target Population \\
\hline Directors & 6 \\
Procurement Unit staff & 13 \\
Contracts Committee members & 5 \\
Marketing and Commercial services & 62 \\
Internal Audit and Risk Management & 53 \\
Quality Assurance staff & 24 \\
Managers & 22 \\
Finance and Accounting staff & 23 \\
Engineering, Planning and Development & 55 \\
\hline Total & $\mathbf{2 6 3}$
\end{tabular}

Source: Researcher (2021).

This publication is licensed under Creative Commons Attribution CC BY.

http://dx.doi.org/10.29322/IJSRP.11.10.2021.p11820 


\subsection{Sample and Sampling Procedure}

The purposive sampling technique was used to for key informants especially Procurement staff and contracts committee members whose holistic involvement adequately informs public interest and expectations of service delivered. This technique was used because it is judgmental such that the researcher selects those elements knowledgeable of the study phenomenon in order to obtain technical information required. According to Mcerudlen (2004), this is done to ensure that a full variety of respondents are obtained from a range of the population. The selected group also was presumed to have an understanding of what is happening in this critical case so that logical generalization was made.
According to Baran and Jones (2016), a sample is a finite part of the population to be studied and gain information that is representative of the whole population. Dealing with the whole population would be costly, time consuming, faces limited cooperation, less accurate, among other limitations and therefore, dealing with a smaller group of population elements yields better research convenience and reliability upon generalizations that apply to the whole population would apply. A sample of 152 was used for the study. A table developed by Krejcie and Morgan (1970) to determine a sample size was used. Basing on the table, 152 was an adequate sample size for a population 263

Table 2: Sample size

\begin{tabular}{llll}
\hline Respondents' category & Population size & Sample size & Sampling technique \\
\hline Directors & 6 & 3 & Simple random \\
Procurement Unit staff & 13 & 13 & Purposive \\
Contracts Committee members & 5 & 5 & Purposive \\
Marketing and Commercial services & 62 & 35 & Simple random \\
Internal Audit and Risk Management & 53 & 30 & Simple random \\
Quality Assurance staff & 24 & 13 & Simple random \\
Managers & 22 & 15 & Simple random \\
Finance and Accounting staff & 23 & 16 & Simple random \\
Engineering, Planning and Development & 55 & 22 & Simple random \\
\hline
\end{tabular}

$\begin{array}{lll}\text { Total } & 263 & 152\end{array}$

Source: Researcher (2021).

\subsection{Data Collection Method}

This study collected two kinds of data that is, primary and secondary data. Primary data was obtained using survey methods including questionnaires and interviewing. Review of documents on contract management was done to collect secondary data. Since no single method of data collection can guarantee one hundred percent accuracy, several methods were used.

\subsubsection{Interviewing}

Interviewing constitutes an oral questioning method of collecting data in which the investigator directly engages in a verbal interaction with participants (Amin, 2005). Interviews were conducted to obtain data on contract management practices in particular contract mobilization, contract monitoring and relationship management and how they link to service delivery targets of Uganda Civil Aviation Authority. These were conducted with key informants like the directors, some managers, and contract committee members. These gave vital and in-depth data on the main study variables.

An interview guide was used to gather consistent general information about contract management practices and service delivery of Uganda Civil Aviation Authority. In addition to answering questionnaires, the interviews targeted key respondents in Uganda Civil Aviation Authority like the Directors, Managers in the Procurement, Finance, Engineering, Marketing and Commercial Services Units. This method was appropriate because it ensured proper understanding and capturing of detailed facts about the various activities associated with contract management practices and service delivery in Uganda Civil Aviation Authority. Face-to-face interactions were planned for before the actual interview of respondents. Advance appointment and agreement on the time of interviews was expedited. At analysis stage, triangulation of interview results with results of other methods is done before drawing conclusions.

\subsubsection{Questionnaire}

Survey is a self-reporting method of collecting data that involves using a questionnaire to gather data about the variables of interest in an investigation (Oppehein, 1996). It gathered data following the detailed statements rhyming with objectives, research questions and hypotheses. The questionnaire method was necessary for this study to give an in-depth and wider coverage of both the unit of investigation and the study variables, and also provide savings in time. The researcher used self-administered questionnaires to collect primary data. These questionnaires were delivered physically by the researcher to respondents who filled them and were collected later by the researcher from the point designated for their return. 


\subsection{Validity and Reliability of Research Instrument}

According to Newman et al. (2013), content validity is an estimate of the representativeness of research instrument items for the content or subject matter sought to be measured by them. Content validity tests were carried out on the main instruments of data collection that is, the self-administered questionnaire. Acceptance was to be based on the Content Validity Index (CVI) results of $\mathrm{CVI} \geq 0.7$ and where it would fall below, and then revisions were to be made based on the advice of the supervisor, technical persons and rerun of the tests done until an acceptable index is reached. The content validity test that involved 5 technical persons in the discipline of contract management had all clear the content of the main instruments i.e., the questionnaire and interview guide to be valid. This gave a CVI of $1>0.7$ to qualify the instruments appropriate for use in the study.

In Taherdoost (2016), Carmines and Zeller (1979) advance that reliability is concerned with the extent to the measurement of phenomenon provides stable and consistent results. This would be through establishing the Cronbach's alpha $(\boldsymbol{\alpha})$ coefficient where, considering a questionnaire reliable, it would have to yield an alpha $(\boldsymbol{\alpha})$ coefficient of $\boldsymbol{\alpha}$ equal or greater than 0.7 as propounded by Nunnaly, (1978). Any value less, would require a revision of the questions, repetition checks, and scaling until the acceptable alpha coefficient is realized. The tests done using the statistical package for social scientists, version 20, gave a Cronbach's Alpha coefficient $\boldsymbol{\alpha}=0.786$ as indicated in table 3 .

Table 3: Cronbach's alpha

\begin{tabular}{lll}
\hline & Cronbach's Alpha Based & N of items \\
Cn & $\begin{array}{l}\text { on } \\
\text { Standardized Items }\end{array}$ & \\
\cline { 2 - 3 } .786 & .753 & 46
\end{tabular}

From table 3, the Cronbach's Alpha coefficient of 0.786 greater than 0.7 implies that the internal consistency of the self-administered questionnaire yielded reliable data for the study.

The study sought to examine the influence of contract mobilization practice on service delivery in Uganda Civil Aviation Authority and findings on this are provided in this section.

IV. DATA ANALYSIS AND DISCUSSION

Influence of Contract Mobilization Practice on Service Delivery in Uganda Civil Aviation Authority

Table 4: Descriptive statistics on Influence of contract mobilization practice on Service Delivery in Uganda Civil Aviation Authority

\begin{tabular}{|c|c|c|c|c|c|}
\hline & $\mathbf{N}$ & Min & Max & Mean & Std. Dev. \\
\hline $\begin{array}{l}\text { Clarification of roles and responsibilities of contracting parties } \\
\text { and other stakeholders are clarified. }\end{array}$ & 110 & 1 & 5 & 3.13 & 0.96 \\
\hline $\begin{array}{l}\text { Contract managers and teams are appointed in accordance with } \\
\text { procedures and guidelines of the PPDA Act. }\end{array}$ & 110 & 1 & 5 & 4.15 & 1.01 \\
\hline $\begin{array}{l}\text { Contract information is clarified and approved to enable } \\
\text { realization of service delivery targets of UCAA. }\end{array}$ & 110 & 1 & 5 & 2.15 & 1.37 \\
\hline $\begin{array}{l}\text { Proposed changes or substitutions by the contractor are subjected } \\
\text { to negotiations in UCAA. }\end{array}$ & 110 & 1 & 5 & 2.71 & 1.31 \\
\hline $\begin{array}{l}\text { Contract management in UCAA ensures that proposed contract } \\
\text { changes are acceptable and cost effective. }\end{array}$ & 110 & 2 & 5 & 4.64 & 0.71 \\
\hline $\begin{array}{l}\text { There is proper documentation of all items agreed upon during } \\
\text { contract management in UCAA. }\end{array}$ & 110 & 1 & 5 & 3.35 & 1.07 \\
\hline
\end{tabular}


Contract management communications are thorough to ensure stakeholders commit to service delivery requirements in UCAA.

Contract documentation is filed and shared with other contracting parties.

Contract implementation and supplier management plans are drawn in UCAA

Contract mobilization in UCAA is collaborative involving representation from all stakeholders
110

1

5

2.32

1.41

110

110

2

2

110

110

1

1

2

It was established that, as required under the PPDA Act, contract managers and teams are appointed following set procedures and guidelines given a mean of 4.15 [Mean=4.15] and a standard deviation of $1.01 \quad[\mathrm{SD}=1.01]$, proposing contract changes or substitutions were found to be very effective practices during contract mobilization at UCAA with a mean of 4.64 and standard deviation of 0.71 [Mean $=4.64, \mathrm{SD}=0.71$ ]; good practice on contract implementation and supplier management planning during contract mobilisation was established with a mean of 4.08 [Mean=4.08] and a low standard deviation of 0.93 [SD=0.93]; and with a mean of 3.13 [Mean=3.13] and standard deviation at 0.96, clarifying roles and responsibilities of parties before contract performance commences has a positive strong influence on service delivery in Uganda Civil Aviation Authority. Furthermore, mobilization involving documentation of all agreed items, sharing them, and including them in the contract file was found to be at moderately strong levels of practice in Uganda Civil Aviation Authority with means of 3.35 and 3.46 and standard deviations of 1.07 and 1.05 respectively.
Negotiation of proposed changes or substitutions by the contractor as a key aspect of post-tender negotiations had a mean of 2.71 and standard deviation of 1.31 indicating a moderate practice; and means of 2.32 and 2.43 with standard deviations of 1.41 and 1.38 , the later indicating spread of scores away from the mean, contract management communications and stakeholder collaboration were found to be weak in UCAA. Investigations indicated a very weak commitment to clarification and approval of contract information to enable realization of service delivery targets in Uganda Civil Aviation Authority given a mean=2.15 and standard deviation $=1.37$. This implied that, lack proper contract information clarity during contract mobilization has failed the attainment of better value for money service delivery in Uganda Civil Aviation Authority.

Correlation Analysis of Contract Mobilization Practice and Service Delivery in Uganda Civil Aviation Authority

A correlation analysis was done to determine the influence of contract mobilization practice on service delivery in Uganda Civil Aviation Authority and results were as indicated in table 5.

Table 5: Correlation of Contract Mobilization Practice and Service Delivery in Uganda Civil Aviation Authority

\begin{tabular}{|c|c|c|c|c|}
\hline & & $\begin{array}{l}\text { Contract } \\
\text { Practice }\end{array}$ & Mobilization & Service Delivery \\
\hline \multicolumn{2}{|c|}{ Contract Mobilization Pearson Correlation } & 1 & & $.680^{* *}$ \\
\hline \multirow{2}{*}{ Practice } & Sig. (2-tailed) & & & .002 \\
\hline & $\mathrm{N}$ & 110 & & 110 \\
\hline \multirow[t]{3}{*}{ Service Delivery } & Pearson Correlation & $.680^{* *}$ & & 1 \\
\hline & Sig. (2-tailed) & .002 & & \\
\hline & $\mathrm{N}$ & 110 & & 110 \\
\hline
\end{tabular}

a. Predictors: (Constant), Contract Mobilization Practice

From table 5, correlation results indicated a strong positive influence of Contract Mobilization practice on Service delivery in Uganda Civil Aviation Authority given $r=0.680$ at significance levels $p=0.002$ less than 0.01 . This implies that an improvement in Contract Mobilization practices of Uganda Civil Aviation Authority will bring about a strong improvement in service delivery.
Analysis of Variance (ANOVA) for Contract Mobilization Practice and Service Delivery in Uganda Civil Aviation Authority

An analysis of variance (ANOVA) test to establish the $\mathrm{F}$ value and its statistical significance was done, yielding results as shown in table 6.

Table 6: Analysis of Variance (ANOVA) for Contract Mobilization Practice and Service Delivery in Uganda Civil Aviation Authority

\begin{tabular}{llllll}
\hline Model Sum of Squares & df & Mean Square & F & Sig. \\
\hline
\end{tabular}




\begin{tabular}{|c|c|c|c|c|c|c|}
\hline \multirow[t]{3}{*}{1} & Regression & 75.286 & 1 & 75.286 & 16.945 & $.001^{\mathrm{a}}$ \\
\hline & Residual & 3.439 & 109 & .031 & & \\
\hline & Total & 78.725 & 110 & & & \\
\hline
\end{tabular}

a. Predictors: (constant), Contract Mobilization Practice

b. Dependent Variable: Service Delivery.

From table 6, it is given that $F=16.945$ and a Sig. value of 0.001 .

This indicates that Contract Mobilization practice has a significant positive influence on service delivery in Uganda Civil Aviation Authority.
Influence of Contract Monitoring Practice on service delivery in Uganda Civil Aviation Authority

The study sought to examine the influence of Contract Monitoring practice on service delivery in Uganda Civil Aviation Authority.

Table 7: Descriptive Analysis on Contract Monitoring Practice on Service delivery in Uganda Civil Aviation Authority

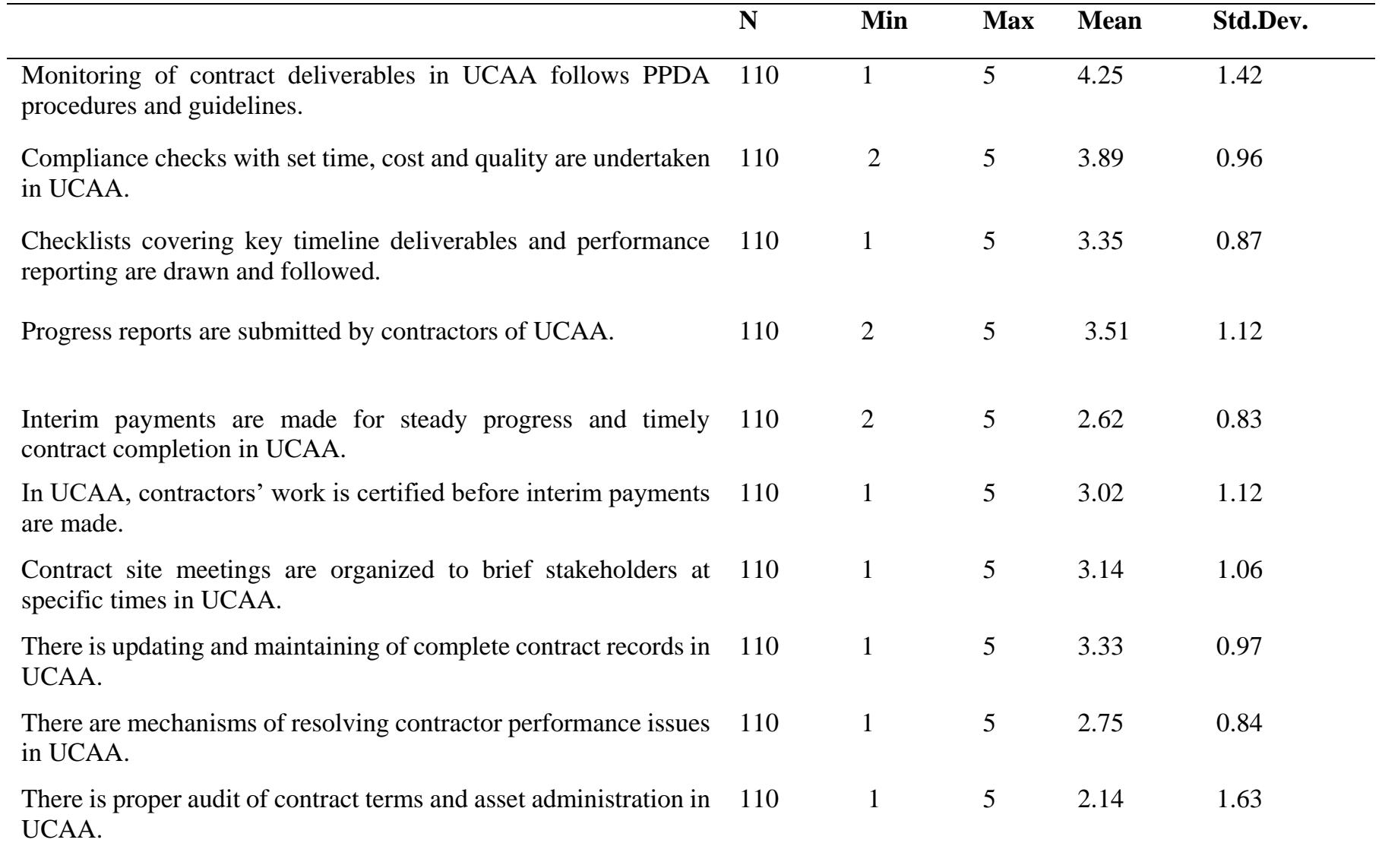

\section{Source: Researcher (2021)}

As provided under Regulation 263 of the PPDA Act 2003, Monitoring of Contracts in Uganda Civil Aviation Authority should adhere to the procedures and guidelines set out in the Act. The study established that, Monitoring of Contract deliverables in Uganda Civil Aviation Authority.

was very high in complying with PPDA procedures and guidelines given a mean of 4.25 and standard deviation at 1.42, Uganda Civil Aviation Authority is highly involved in compliance checks on quality, time and cost given a mean 3.89 and standard deviation of 0.96 , measuring and reporting of progress made against key performance indicators set out in the contract, submission of progress reports in Uganda Civil Aviation Authority was found at high compliance levels given a mean of 3.51 and standard deviation $=1.12$ implying its significance in improving service delivery.

The use of performance checklists during contract monitoring and performance reporting yielded a mean $=3.35$ with a standard deviation of 0.87 ; there was a moderately strong agreement Uganda Civil Aviation Authority.

updates and maintains complete contracts records given a mean $=3.33$ with scores clustered around the mean given a low standard deviation of 0.97; and a review of the 2017 Auditor General's Report on Uganda Civil Aviation Authority disclosed concerns over inadequate update and maintenance of complete contract records. The study established moderately strong levels of compliance with holding site meetings and certification of contractors' work before payments are made in Uganda Civil 
Aviation Authority given mean=3.14, $\mathrm{SD}=1.06$ and Mean=3.02, $\mathrm{SD}=1.12$ respectively as indicated in table 7 .

The study established moderate practice of interim payments and resolution of contractor performance issues in Uganda Civil Aviation Authority given respective means $=2.62$ and 2.75 with standard deviations of 0.83 and 0.84 respectively. This facilitated the satisfaction of time requirements and efficient service delivery as reported on execution of the contract for automating the Aeronautical Information Management System at the Airport. Such interim payments and cooperation with contractor have enabled timely completion of contracts.

Based on the recommended practice by Gower (2003) and Elsey (2007) to have audit of terms of contract and liaison with contractor on matters of asset administration respectively, contract monitoring practice in Uganda Civil Aviation Authority was found to be less compliant with a mean score of 2.14 and a standard deviation of 1.63. This reluctance by Uganda Civil Aviation Authority to have effective audit of contract terms on price, discounts, payment and receipt, compliance with service level agreements and quality, accounts for the failure to realize optimal value for money and improved service delivery outcomes from contracts.

Correlation Analysis of Contract Monitoring Practice and Service Delivery in Uganda Civil Aviation Authority

A correlation analysis was done to determine the influence of Contract Monitoring practice on Service delivery in Uganda Civil Aviation Authority and results were as indicated in table 8.

Table 8: Correlation Analysis of Contract Monitoring Practice and Service Delivery in Uganda Civil Aviation Authority

\begin{tabular}{lll}
\hline Correlations & $\begin{array}{l}\text { Contract } \\
\text { Practice }\end{array}$ & Monitoring Service Delivery
\end{tabular}

\begin{tabular}{llll}
\hline $\begin{array}{l}\text { Contract Monitoring } \\
\text { Practice }\end{array}$ & Pearson Correlation & 1 & $.629^{* *}$ \\
& Sig. (2-tailed) & 110 & .000 \\
& $\mathrm{~N}$ & & 110 \\
Service Delivery & & $.629^{* *}$ & 1 \\
& Pearson Correlation & .000 & 110 \\
\hline & Sig. (2-tailed) & 110 & \\
\hline
\end{tabular}

a. Predictors: (Constant), Contract Monitoring Practice

From table 8, correlation results indicate a moderately strong positive influence of contract monitoring practice on service delivery in Uganda Civil Aviation Authority given $r=$ 0.629 at significance levels $p=0.000$ that is less than 0.01 . This implies that an improvement contract monitoring practice at Uganda Civil Aviation Authority will bring about a moderate improvement in service delivery.
Analysis of Variance (ANOVA) for Contract Monitoring practice and Service Delivery in Uganda Civil Aviation Authority

An analysis of variance test to establish the $F$ value and its statistical significance that indicate this variance between Contract Monitoring practice and service delivery was done, yielding results as shown in table 9.

Table 9: Analysis of Variance (ANOVA) for Contract Monitoring practice and Service Delivery in Uganda Civil Aviation Authority

\begin{tabular}{|c|c|c|c|c|c|}
\hline Model & Sum of Squares & df & Mean Square & $\mathbf{F}$ & Sig. \\
\hline $\begin{array}{ll}1 & \text { Regression } \\
& \text { Residual } \\
& \text { Total }\end{array}$ & $\begin{array}{l}83.027 \\
2.748 \\
85.775\end{array}$ & $\begin{array}{l}1 \\
109 \\
110\end{array}$ & $\begin{array}{l}83.027 \\
.025\end{array}$ & 13.673 & $.000^{\mathrm{a}}$ \\
\hline
\end{tabular}

a. Predictors: (constant), Contract Monitoring Practice

b. Dependent Variable: Service Delivery.

From table 9, the results indicates $\mathrm{F}=13.673$ and a Sig. value of 0.000 . This shows that Contract Monitoring practice has a significant positive influence on service delivery in Uganda Civil Aviation Authority. Contract monitoring practice is thus important to delivery of satisfactory service in Uganda Civil Aviation Authority given the low levels of variance at $13.673 \%$ and levels of significance at 0.000 that is less than 0.01 .

Influence of Relationship Management Practice on Service Delivery in Uganda Civil Aviation Authority
This section gives a presentation, analysis and interpretation of findings on the influence of relationship management on service delivery in Uganda Civil Aviation Authority. It gives descriptive statistics by way of means and standard deviations. From table 10, the study established that Uganda Civil Aviation Authority is highly involved in notifying contractors of key personnel to contracts as well as clarification of their roles and responsibilities given a mean of 4.09 with scores clustered around it based on the low standard deviation of 0.63. Similarly, Uganda Civil Aviation Authority is highly compliant with clarifying of roles and responsibilities of parties to contract 
given a mean of 4.14 with scores clustered around the mean due to the low standard deviation of 0.58 [Mean $=4.14, \mathrm{SD}=0.58]$.

Table 10: Descriptive findings on Relationship Management Practice in Uganda Civil Aviation Authority

\begin{tabular}{|c|c|c|c|c|c|}
\hline & $\mathbf{N}$ & Min & Max & Mean & Std.Dev. \\
\hline $\begin{array}{l}\text { Relationship management is given importance during contract } \\
\text { management in UCAA }\end{array}$ & 110 & 2 & 5 & 3.98 & 0.75 \\
\hline In UCAA, contractors are notified of personnel relevant to contracts & 110 & 1 & 5 & 4.09 & 0.63 \\
\hline $\begin{array}{l}\text { Roles and responsibilities of contract parties are clearly established in } \\
\text { UCAA. }\end{array}$ & 110 & 2 & 5 & 4.14 & 0.58 \\
\hline $\begin{array}{l}\text { Modalities for effective communication between UCAA and contractors } \\
\text { are usually well-structured. }\end{array}$ & 110 & 1 & 5 & 3.52 & 1.36 \\
\hline $\begin{array}{l}\text { Functional requirements of UCAA are always harmonized with those of } \\
\text { its contractors. }\end{array}$ & 110 & 1 & 5 & 3.49 & 0.71 \\
\hline $\begin{array}{l}\text { Implementation schedules of contractors and sub-contractors are } \\
\text { effectively coordinated in UCAA. }\end{array}$ & 110 & 1 & 5 & 3.27 & 1.01 \\
\hline $\begin{array}{l}\text { Interface management programmes of UCAA with its contractors are } \\
\text { common practice. }\end{array}$ & 110 & 1 & 5 & 2.30 & 0.46 \\
\hline $\begin{array}{l}\text { Relationship management centers on the key performance indicators of } \\
\text { quality, cost and time. }\end{array}$ & 110 & 1 & 5 & 3.41 & 0.82 \\
\hline $\begin{array}{l}\text { Regular reports on performance and critical contract management issues } \\
\text { are shared in UCAA. }\end{array}$ & 110 & 1 & 5 & 3.56 & 1.15 \\
\hline $\begin{array}{l}\text { Conflict resolution mechanisms and common risk management plans are } \\
\text { usually in place in UCAA. }\end{array}$ & 110 & 1 & 5 & 3.72 & 0.88 \\
\hline
\end{tabular}

\section{Source: Researcher (2021)}

A mean of 3.98 and standard deviation of 0.75 [Mean $=3.98$, $\mathrm{SD}=0.75$ ] established that relationship management is an important practice in the management of in Uganda Civil Aviation Authority; with a mean $=3.52$ and standard deviation of 1.36 [Mean=3.52, $\mathrm{SD}=1.36$ ] as indicated in table 4.5.1, it was established that structures for effective communication are well laid out during contract management in Uganda Civil Aviation Authority; and there was strong agreement on this practice within Uganda Civil Aviation Authority given a mean of 3.49 with scores clustered around it due a low standard deviation of 0.79 [Mean=3.49, SD=0.79]. These imply there is good relationship management practice at Uganda Civil Aviation Authority that let to greater levels of service delivery.

According to the World Bank (2018), regular reporting, conflict resolution and risk management planning are fundamental considerations for effective relationship management during contract management to attain value for money. Examining whether regular reports on performance and critical contract management issues are shared in Uganda Civil Aviation Authority yielded a mean $=3.56$ and standard deviation $=1.15$ [Mean=3.56, $\mathrm{SD}=1.15]$. Conflict resolution mechanisms and common risk management plans had a mean score of 3.72 and a standard deviation of 0.88 [Mean=3.72, $\mathrm{SD}=0.88]$ are usually in place in Uganda Civil Aviation Authority. Thus, value for money is attained from contracts that drives cost effectiveness, quality and efficiency of service delivery with means of 3.27 and 3.41 , and standard deviations of 1.01 and 0.82 respectively and moderately strong compliance with coordination of implementation schedules and centering on key performance indicators in Uganda Civil Aviation Authority. Document reviews revealed that implementation schedules and key performance indicators have been a point reference in shaping the ongoing relationship between Uganda Civil Aviation Authority and its key contractors like China Construction Communications Company (CCCC) and Vanderlande Industries B.V of Netherlands. However, interview discussions indicated strained relations with some contractors like Global Consulting Services Limited. The lowest levels of compliance with required practice were established in regard to the use of interface management programmes in Uganda Civil Aviation Authority. The findings indicate a low mean of 2.30 and very standard deviation of 0.46 that is, mean $=2.30, \mathrm{SD}=0.46$ as indicated in table 10.

\section{Correlation Analysis of Relationship Management Practice and Service Delivery in Uganda Civil Aviation Authority}

A correlation analysis was done to determine the influence of relationship management practice on service delivery in Uganda Civil Aviation Authority and results were as indicated in table 11 .

Table 11: Correlation Analysis of Relationship Management Practice and Service Delivery in Uganda Civil Aviation Authority 


\begin{tabular}{llll}
\hline Relationship & Pearson Correlation & 1 & $.709^{* *}$ \\
Management & Sig. (2-tailed) & 110 & .000 \\
Practice & N & $.709^{* *}$ & 110 \\
Service Delivery & Pearson Correlation & .000 & 1 \\
& Sig. (2-tailed) & 110 & 110 \\
\hline
\end{tabular}

a. Predictors: (Constant), Relationship Management Practice

From table 11, correlation results indicate a strong positive influence of relationship management practice on service delivery in Uganda Civil Aviation Authority given $r=0.709$ at significance levels $p=0.000$ less than 0.01 . This implies that an improvement relationship management practice of Uganda Civil Aviation Authority will bring about a relatively big improvement in service delivery.
Analysis of Variance (ANOVA) for Relationship Management Practice and Service Delivery in Uganda Civil Aviation Authority

An analysis of variance test to establish the $\mathrm{F}$ value and its statistical significance that indicates this variance between relationship management practice and service delivery was done, yielding results as shown in table 12 .

Table 12: Analysis of Variance (ANOVA) for Relationship Management Practice and Service delivery in Uganda Civil Aviation Authority

\begin{tabular}{lllllll}
\hline Model & Sum of Squares & df & Mean Square & F & Sig. \\
\hline 1 & Regression & 74.159 & 1 & 74.159 & 9.013 & $.000^{\mathrm{a}}$ \\
& Residual & 3.226 & 109 & .029 & & \\
& Total & 77.385 & 110 & &
\end{tabular}

a. Predictors: (constant), Relationship Management Practice

b. Dependent Variable: Service Delivery.

From table 12, it is given that $\mathrm{F}=9.013$ and a Sig. value of 0.000 . This indicates that relationship management practice has a significant positive influence on service delivery in Uganda Civil Aviation Authority. Relationship management practice is thus very important to achievement of desired service delivery in
Uganda Civil Aviation Authority given the low levels of variance at $9.013 \%$ and levels of significance at 0.000 less than 0.01 .

\section{Regression Model summary for independent variables}

To establish the degree of influence Contract Management practices have on service delivery in Uganda Civil Aviation Authority, it was critical to have a multiple regression coefficient established as indicated in the model summary table 13

Table 13: Model Summary

\begin{tabular}{lllll}
\hline Model & R & R Square & Adjusted R Square & Std. Error of the Estimate \\
\hline 1 & $.683^{\mathrm{a}}$ & .466 & .452 & 1.10252 \\
\hline
\end{tabular}

a. Predictors: (Constant), C Mobilization practice, C Monitoring practice, RM practice

From table 13, it can be drawn that, the multiple regression coefficient (R) for all predictors that include Contract Mobilization practice, Contract Monitoring practice, and Relationship Management practice is 0.683 , $\mathrm{R}$ square $=0.466$, and adjusted $\mathrm{R}$ square is 0.452 . This implies that contract management practices have a moderately strong positive influence on service delivery in Uganda Civil Aviation Authority given $r=0.683$. This influence on service delivery in Uganda Civil Aviation Authority is $46.6 \%$ a result of a value change in Contract Mobilization practice, Contract Monitoring practice, and Relationship Management practice determined at $45.2 \%$ accuracy levels. The remaining $53.4 \%$ change in service delivery within Uganda Civil Aviation Authority is a result of other influencing factors not covered in the current study. The model $\boldsymbol{y}=\boldsymbol{\beta}_{\mathbf{0}}+\boldsymbol{\beta}_{\mathbf{1}} \boldsymbol{x}_{\mathbf{1}}+$ $\boldsymbol{\beta}_{2} \boldsymbol{x}_{\mathbf{2}}+\boldsymbol{\beta}_{\mathbf{3}} \boldsymbol{x}_{\mathbf{3}}+\boldsymbol{\varepsilon}$ explained $45.2 .0 \%$

Table 14: Coefficients' Relationship between the independent variables and Service delivery in Uganda Civil Aviation Authority 


\begin{tabular}{|c|c|c|c|c|c|}
\hline \multirow[t]{2}{*}{ Model } & \multicolumn{2}{|c|}{$\begin{array}{l}\text { Unstandardized } \\
\text { Coefficients }\end{array}$} & \multicolumn{2}{|l|}{$\begin{array}{l}\text { Standardized } \\
\text { coefficients }\end{array}$} & \multirow[b]{2}{*}{ Sig. } \\
\hline & $\mathrm{B}$ & Std. Error & Beta & $\mathrm{t}$ & \\
\hline $1 \quad$ (Constant) & 6.241 & 2.671 & & 2.043 & .002 \\
\hline Contract mobilization practice & 0.113 & 0.056 & 0.201 & 1.875 & .003 \\
\hline Contract monitoring practice & 0.157 & 0.049 & 0.113 & 0.706 & .001 \\
\hline
\end{tabular}

a. Dependent Variable: Service delivery

Standardized coefficients in table 14 further indicate a positive influence of the contract management practices on service delivery in Uganda Civil Aviation Authority. In other words, service delivery in Civil Aviation Authority is positively influenced by contract mobilization practice with $\beta=0.201$ and sig. value $\mathrm{p}=0.003<0.01$; Contract Monitoring practice with $\beta=0.113$ and sig. value of $p=0.001<0.01$; and relationship management practice with $\beta=0.002$ with sig. value of $\mathrm{p}=0.002<0.01$. These results imply that the three predictors that is, contract mobilization practice, Contract Monitoring practice, and Relationship Management practice have a significant positive influence on service delivery in Uganda Civil Aviation Authority. Of the three predictors, relationship management practice has a greater influence on service delivery than contract Mobilization and monitoring practices in Uganda Civil Aviation Authority given a higher beta value of $\beta=0.365$. So, an improvement in relationship management practice within contract management activities of Uganda Civil Aviation Authority will bring about a significant improvement in service delivery. Presentation of the regression Model:

$\mathrm{Y}=\beta 0+\beta 1 \mathrm{X} 1+\beta 2 \mathrm{X} 2+\beta 3 \mathrm{X} 3+\varepsilon$

Where $\mathrm{Y}=$ Institutional Procurement Performance

$\beta 0=$ Constant Term $\beta 1, \beta 2, \beta 3$, = Coefficients.

$\mathrm{X} 1=$ Contract mobilization practice, $\mathrm{X} 2=$ Contract monitoring practice; $\mathrm{X} 3=$ Relationship management practice; and $\varepsilon=$ Error Term

$\beta 0=6.241 ; \beta 1=0.113, \beta 2=0.157$, and $\beta 3=-0.205$

Hence the general regression model was $\boldsymbol{y}=\mathbf{6 . 2 4 1 +}$ $0.113 x_{1}+0.157 x_{2}+0.205 x_{3}+\varepsilon$

\section{SUMMARY OF THE FINDINGS.}

The Contract Management Practices has a moderately strong positive influence on service delivery in Uganda Civil Aviation Authority given $r=0.683$. This influence on service delivery in Uganda Civil Aviation Authority is $11.3 \%$ a result of a value change in Contract Mobilization practice, Contract Monitoring practice at $\mathbf{1 5 . 7 \%}$, and Relationship Management practice determined at $20.5 \%$ accuracy levels. The remaining $52.5 \%$ change in service delivery within Uganda Civil Aviation Authority is a result of other influencing factors not covered in the current study

Contract Mobilization Practice, $r=0.201$ and contract monitoring $\mathrm{r}=0.113$ have a moderate positive influence on service delivery in Uganda Civil Aviation Authority. Relationship management $r=0.365$ has a stronger positive influence on Service delivery than contract Mobilization practice and Contract monitoring practice.
On contract monitoring practice and service delivery in Uganda Civil Aviation Authority, the study established very high levels of compliance with PPDA procedures and guidelines. It was further established that, Uganda Civil Aviation Authority is highly involved in compliance checks on the triple constraint factors of quality, time and cost in its contract monitoring practice. Most respondents agreed that performance checklists covered deliverables based on set timeframes, specified quality standards, set budgets, and such performance established is reported in Uganda Civil Aviation Authority. It was established that; updating and maintenance of complete contracts records, holding site meetings, and certification of contractors' work before payments are made in Uganda Civil Aviation Authority. Interim payments and resolution of contractor performance issues were established as moderate contract monitoring practices in Uganda Civil Aviation Authority. However, audit of contract terms and asset administration were established to be poorly practiced in Uganda Civil Aviation Authority.

It was established that structures for effective communication are well laid out during contract management in Uganda Civil Aviation Authority and strong agreement on harmonization of functional requirements with those of contractors. Regular reporting, conflict resolution and risk management planning were found to be fundamental practices in Uganda Civil Aviation Authority. Hence, value for money is attained from contracts that drives cost effectiveness, quality and efficiency of service delivery. Implementation schedules of contractors and sub-contractors are effectively coordinated and relationship management centers on the key performance indicators of quality, cost and time in Uganda Civil Aviation Authority even though majority of respondents were in disagreement with the use of interface management programmes in the relationship management practice of Uganda Civil Aviation Authority with its contractors.

\section{CONCLUSION}

The Contract Management Practices has a moderate positive influence on service delivery in Uganda Civil Aviation Authority given $r=0.683$. This influence on service delivery in Uganda Civil Aviation Authority is $11.3 \%$ a result of a value change in Contract Mobilization practice, Contract Monitoring practice at $15.7 \%$, and Relationship Management practice determined at $20.5 \%$ accuracy levels. The remaining $52.5 \%$ change in service delivery within Uganda Civil Aviation Authority is a result of other influencing factors not covered in the current study 
Contract Mobilization Practice, $r=0.201$ and contract monitoring $\mathrm{r}=0.113$ have a moderately strong positive influence on service delivery in Uganda Civil Aviation Authority. Relationship management $r=0.365$ has a stronger positive influence on Service delivery than contract Mobilization practice and Contract monitoring practice.

Relationship management being of paramount importance to successful Contract Management, notifying contractors of personnel relevant to contracts, clearly establishing the roles and responsibilities of parties, structuring of modalities for effective communication, and harmonization of functional requirements of Uganda Civil Aviation Authority with those of its contractors will lead to significant improvement in service delivery.

Similarly, coordination of implementation schedules of contractors and sub-contractors, developing interface management programmes of Uganda Civil Aviation Authority with its contractors, centering on the key performance indicators of quality, cost and time; regular performance reporting, sharing of critical contract management issues, conflict resolution mechanisms, and risk management planning will optimize service delivery in Uganda Civil Aviation Authority

\section{RECOMMENDATIONS}

Greater focus on relationship management as key practice of contract management is recommended to guide the attainment of better levels of service delivery from contracts of supplies, services and works in the public sector. Improvement of relationships in contract management through communications, multidisciplinary stakeholder collaboration, commitment to clarification and approval of contract information will enable greater realization of service delivery targets in Uganda Civil Aviation Authority.

The study further recommends better update and maintenance of complete contracts records, holding site meetings, and certification of contractors' work before payments are made in Uganda Civil Aviation Authority to ensure that contract monitoring delivers more optimal solutions to service delivery in the public sector. Also, improved management of interim payments and resolution of contractor performance issues in contract monitoring, are critical practices in influencing more optimal service delivery from contracts.

There should be a significant improvement in audit of contract terms and asset monitoring practices to ensure Uganda Civil Aviation Authority and other public sector entities deliver more effective service to the public. Interface management programmes in the relationship management practice of Uganda Civil Aviation Authority with its contractors should be mainstreamed as they form a critical component that nurtures more efficient and effective relationships that facilitate multistakeholder cooperation

\section{REFERENCES}

[1] Abutabenjeh. S. and Jaradat, R.(2018). Clarification of research design, research methods, and research methodology: A guide for public administration researchers and practitioners, Teaching Public Administration Journal, 2018, Vol. 36(3) 237-258.

This publication is licensed under Creative Commons Attribution CC BY

http://dx.doi.org/10.29322/IJSRP.11.10.2021.p11820
[2] Amin, M.E. (2005): Social Science Research: Conception, Methodology and Analysis Kampala, Makerere University Printery.

[3] Anglin, C. J., \& Good, J. D. (2009): Contract Management Process and Mentorship Analysis of United States Special Operations Command's (USSOCOM) Special Operations Acquisition and Logistics Directorate of Procurement (SOAL-K): MBA Professional Report, Naval Postgraduate School, Monterey, CA.

[4] Baran Mette and Jones Janice (2016). Mixed Methods Research for Improved Scientific Study: A volume in the Advances in Knowledge Acquisition, Transfer, and Management (AKATM) Book Series: pp.122, Information Science Reference, IGI Global.

[5] CAA (2016). Uganda Civil Aviation Authority: Directorate of Corporate Affairs, Entebbe: Uganda Civil Aviation Authority (CAA). Retrieved 22 October 2016

[6] CIPS(2013). Purchasing and Supply Management: Supplier Relationship Management, CIPS Position on Practice, Leading global excellence in Procurement and Supply, pp.1-6.

[7] CIPS, (2014): Developing Contracts: a practical guide: A CIPS Publication.

[8] Cresswell J. W. (2014). Selection of a Research Approach: Chapter One: Preliminary Considerations, In J.W. Creswell (Eds.), pp.1-23, Thousand Oaks, Sage Publications.

[9] Creswell, J. W. (2003). Research Design: Qualitative, Quantitative, and Mixed Methods Approaches. Thousands Oaks, CA: Sage.

[10] Darwin; J, Duberley J, and Phil, J. (2000): "Contracting in ten English local authorities: preferences and reservations: MCB UP Ltd.

[11] Errigade, A. \& Mclloy, J., (2002): Public Procurement and supply management strategies, public policy and Administration. Volume 17, No 1.Spring pp52-7i

[12] Gathai, W. E., Ngugi, K. J., Waithaka, M. S., and Kaminji, N. C., (2012) Analysis of Factors That Influence Implementation of Performance Contracts in State Corporations (A Case of Kenya Civil Aviation Authority), International Journal of Humanities and Social Science, Vol. 2 No. 17; September 2012.

[13] Hotteebex, B. (2013). Effective Contract Management: Monitoring Contractor's Performance, 1st Publication, McMillan.

[14] Hunja, R.R. (2003) Obstacles to Public Procurement Reforms in developing economies, OECD \& World Bank Publication.

[15] Kabir Syed Muhammad Sajjad (2016). Sample and Sampling Designs, Curtin University, Chapter 7, pp.168-181, Research Gate.

[16] Kibogo A. Daina (2014) Factors Affecting Contract Management in Public Procurement Sector in Kenya: A Case of Kenya Literature Bureau, Corpus ID: 168270844

[17] Komakech Robert Agwot (2020). Contract Management and Service Delivery in Local Governments in Uganda: International Journal Advances in Social Science and Humanities. Vol. 08, Issue 02, pp.01-23.

[18] Kothari, C.R. (2004). Research Methodology, New Delhi: New Age International Publishers.

[19] Kramer,W. T., (2003). The rules of Fraud, Risk management, 50(11):54.

[20] Krejcie, Robert V., and Morgan, Daryle W., (1970): "Determining Sample Size for Research Activities": Educational and Psychological Measurement: Reprint, Kogan Page.

[21] Kumar Rajit (2011). Research Methodology: a step-by-step guide for beginners, 3rd Edition, London, Sage Publications Ltd.

[22] Kumar, R. and Markeset, T. (2013): Subsea maintenance service delivery: A multi-variable analysis, Emerald Group Publishing Limited.

[23] Lock Dennis, (2003): Project Management, London, Eighth Edition, McGraw-Hill.

[24] Lonegan Eoin and King Bernadette, (2003): Legal and Procurement Processes - Study Guide, Revised edition, CIPS

[25] Mampane. K., (2012). Supplier Relationship Management, Gauteng Branch Meeting, pp.17-24.

[26] Mbabazi, T. (2007): A Guide to Research and Research Methods, Jotain Co. Ltd, Kampala, Uganda.

[27] Mcerudlen (2004): Investigating the effectiveness of using case studies in conducting research studies.

[28] Mwakyelu M. Josephine (2019). Challenges facing contract management in the public procurement: a case study of Tanesco in Iringa Municipality, Tanzania, Student Research. 
[29] Nadiope, M. (2005): Effects of Contract Management methods of donor founded projects on the construction industry in Uganda

[30] Nakaweesi, D. (9 July 2019). “Airline Regulator Changes Name”, Daily Monitor, Kampala. Retrieved 11 July 2019.

[31] Nunally, J.C. (1978): Psychometric Theory, McGraw-Hill, New York.

[32] OECD (2008): Health care working papers-Service Delivery Indicators Project Initial Indicators Report, 2008, No. 18.

[33] Office of Government Commerce, (2002). Principles of Service Contracts Contract Management guidelines: UK.

[34] O'Neill, M. W. and Lymon, C. (2010): Construction Procedures and LRFD Design: A May 10, 2010, Reese, Publication No. 39.

[35] Oppehein, A.N. (1996): Questionnaire design, Interviewing and Attitude Measurement, Printer Publishers, London, UK

[36] Public Procurement and Disposal of Public Assets Authority, (2010): Training and capacity Building development procurement and disposal capacity building strategy report $2011-2014$

[37] Reader Paul (2019). Procurement Options: Contract Mobilisation in Repair and Maintenance Contracts, pp.8, Mitie Group Inc.

[38] Taherdoost Hamed (2016). Validity and Reliability of the Research Instrument: How to Test the Validation of a Questionnaire/Survey in a Research, International Journal of Academic Research in Management (IJARM), Vol. 5, No. 3, 2016, pp.28-36, Helvetic Editions LTD, Switzerland.

[39] Tajuba, Paul (30 January 2015). "CAA unveils master plan to create four new international airports". Daily Monitor. Kampala. Retrieved 30 January 2015.

[40] Taylor, W. (2009). A practical Guide to successful contract management: Taylor Walton technology and outsourcing group.
[41] Telgren, J., and Luitzen, de Boer. (1998): Purchasing Practices in Dutch Municipalities, International Journal of Purchasing and Materials Management.

[42] Uganda, Ministry of Local Government, Decentralization Policy Strategic Framework, 2004.

[43] Weele, Van A. (2002): "Purchasing and Supply Chain Management Analysis, Planning and Practice", 3rd Edition, Thomson Learning, London.

[44] World Bank (2013). Service delivery in the Public Sector: Indicators and Measures. www.worldbank.org/SDI.

[45] World Bank (2017). Contract Management: General Principles, Washington, 1st Edition, September, 2017, pp.23-24.

\section{AUTHORS}

First Author - Mr. James Anthony Kenyi, School of Business and Economics, Mount Kenya University-Thika, O/C UNMISS HQ, BOX 29 -8111 JUBA, SOUTH SUDAN, Email:

kenyij56@gmail.com

Second Author - Dr. Peter Wamalwa Barasa, PhD, School of Business and Economics, Mount Kenya University-Thika, P.O BOX 42702- 80100, MOMBASA KENYA, Email:

petbar2001us@yahoo.com 